\title{
Preparation and characterization of the antibody recognizing AMACR inside its catalytic center
}

\author{
BORIS V. POPOV ${ }^{1,2}$, GLEB I. SUTULA ${ }^{1}$, NIKOLAY S. PETROV ${ }^{1,3}$ and XIMING J. YANG ${ }^{2}$ \\ ${ }^{1}$ Institute of Cytology, Russian Academy of Sciences, 194064 St. Petersburg, Russia; \\ ${ }^{2}$ Robert H. Lurie Comprehensive Cancer Center, Department of Pathology, Northwestern University, \\ Chicago, IL 60611; ${ }^{3}$ Developmental Therapeutics Branch, National Cancer Institute, \\ National Institutes of Health, Bethesda, MD 20892-4264, USA
}

Received September 6, 2017; Accepted December 1, 2017

DOI: $10.3892 /$ ijo.2017.4220

\begin{abstract}
Alpha-methylacyl-CoA racemase (AMACR) catalyzes the $\beta$-oxidation of fatty acids and is overexpressed in carcinomas in various organs, while its inactivation results in the inhibition of cancer growth. In the present study, we prepared and characterized 20 different mouse monoclonal antibodies against human AMACR. In the course of biopanning of a phage peptide commercial library against in-house prepared $6 \mathrm{H} 9$ and $2 \mathrm{~A} 5$, and commercial $13 \mathrm{H} 4$ antibodies, 10 phage mimotopes recognized by each type of the antibody were selected. Using the program Pepitope and the crystal structure of AMACR from Mycobacterium tuberculosis, we reveal for the first time, at least to the best of our knowledge, that the epitopes recognizing the antibody against AMACR are composed of conformation sequences localized inside the AMACR catalytic center. When delivered into live HeLa cells using cationic lipid-based PULSin reagent, the specific antibodies against AMACR were co-localized with peroxisomes. The in-house made $6 \mathrm{H} 9$ antibody exhibited a low level of this co-localization compared to the commercially available 63340 antibody, and did not inhibit the growth rate of HeLa and T98G cells. The results obtained suggest that antibody against AMACR may possess anti-AMACR catalytic activity and needs to be further investigated as a potential drug for use in anticancer therapy. On the whole, in this study, we generated several clones of AMACR antibodies and demonstrated that these antibodies can be colonized into live cells. Currently, we are testing the growth inhibitory properties of these antibodies against AMACR.
\end{abstract}

Correspondence to: Dr Boris V. Popov, Laboratory of Cell Pathology, Institute of Cytology, Russian Academy of Sciences, 4 Tikhoretsky Avenue, 194064 St. Petersburg, Russia

E-mail: borisvp478@gmail.com

Key words: alpha-methylacyl-CoA racemase, antibody, epitopes, antibody anticancer activity

\section{Introduction}

Alpha-methylacyl-CoA racemase (AMACR) catalyzes the reverse transition of (2R)-methylacyl-CoA and (2S)-methylacyl-CoA $(1,2)$ required for the $\beta$-oxidation of fatty acids and the synthesis of bile acids $(3,4)$. The metabolism of fatty acids is activated in tumor tissue that is associated with the increased production of AMACR, providing unique benefits for the active proliferation of cancer cells $(5,6)$. The increased consumption of foods containing fatty acids, such as animal fat, meat and milk, increases the risk of developing prostate and intestinal cancer (7). By contrast, the inhibition of AMACR production prevents the growth of malignant cells $(8,9)$. AMACR was identified and characterized in 1994 as the enzyme involved in lipid metabolism (10), and its overexpression in prostate adenocarcinoma, but not in benign prostate tissue was found in 2000-2002 (11-15). Thus, AMACR has been widely used as a diagnostic marker for prostate cancer $(16,17)$. Recent publications have indicated the increased production of AMACR, not only in prostate cancer, but also in tumors derived from the epithelium of the intestines, kidneys, liver and embryonic stem cells $(6,18)$. Although the diagnostic value of AMACR detection is evident, the mechanisms regulating an increase in its levels in tumor cells, remain unexplored. The transcriptional analysis of the AMACR proximal promoter has resulted in the identification of the gene regulatory region located between nucleotides -423 and -93 , which is negatively regulated by $\mathrm{C} / \mathrm{EBP} \alpha, \mathrm{p} 53$ and $\mathrm{NF}-\kappa \mathrm{B}$ p50, but does not depend on the signals mediated by the androgen receptor (19). The analysis of the AMACR promoter region has not revealed the binding sites for proteins of the LEF/TCF family; however, available data suggest that the increased expression of AMACR in hepatocellular carcinoma is associated with activating mutations of the $\beta$-catenin gene $(C T N N B 1)$, the product of which transactivates the target genes via interaction with proteins of the LEF/TCF family (20). It is known that $\beta$-catenin plays a role in the regulation of the self-renewal of normal and tumor stem cells of various tissues and is overproduced in cancers originating from different organs (21). Possibly, AMACR is a target of $\beta$-catenin, which causes an increase in AMACR production in the case of $C T N N B 1$ activating mutations. 
Carcinomas of the prostate, colon, kidney and liver, in which the increased production of AMACR has been established, are the leading causes of cancer-related mortality in different parts of the world (22). Therefore, AMACR is considered an important diagnostic marker of cancer and a target of anticancer therapy. Currently, the search for AMACR inhibitors is mainly focused on substances with substrate specificity (9). Some authors have presented the results of prostate cancer immunotherapy using cytotoxic $\mathrm{T}$ lymphocytes that recognize AMACR (23). The possibility of the therapeutic application of antibodies against AMACR has not yet been investigated, at least to the best of our knowledge. This may be associated with the intracellular localization of the protein and its inaccessibility for antibodies. On the other hand, recent studies have revealed the presence of AMACR in biological fluids of patients suffering from cancer $(24,25)$, which indicates the obvious desirability for obtaining and for the characterization of a wide variety of antibodies against AMACR.

The aim of this study was to obtain monoclonal antibodies against human AMACR and to determine and map their epitopes. The Biocompare database currently contains information about 37 companies offering more than 400 different commercial preparations of antibody against AMACR and their derivatives. These preparations are supplied with the description of the different abilities of the antibodies for their usage in various applications, but do not contain characteristics of the epitopes recognized by the antibody.

The first aim of the present study was to obtain the hybridomas producing mouse monoclonal antibody against human AMACR. As an antigen, we used the affinity purified recombinant human protein encoded by the AMACR cDNA of 1,621 base pairs with an open reading frame of 382 AA (GenBank Accession no. NM_014324). The second aim was to describe the specific immune abilities of the antibody and to detect the mimotopes recognized by the in-house made and commercial antibody against AMACR using biopanning of the phage peptide library Ph.D.-7C7 (BioLabs, Linden, NJ, USA) and the sequencing of DNA from the selected phage particles. The third task was to find the epitopes of human and mouse AMACR corresponding to the phage mimotopes using a special Pepitope program (26), an algorithm PepSurf (27), and the crystal structure of AMACR from Mycobacterium tuberculosis (MRC), PDB $1 \times 74$ (1). The final aim was to deliver the antibodies prepared into live cells to estimate their biological activities in cancer cells.

For this purpose, we prepared and characterized 20 murine hybridomas producing monoclonal antibodies recognizing human and mouse AMACR. The antibodies produced by hybridomas $6 \mathrm{H} 9$ and $2 \mathrm{~A} 5$ together with commercial 13H4 rabbit monoclonal anti AMACR antibody were used for biopanning of phage peptide library followed by DNA sequencing of the selected phage clones and mapping the corresponding epitopes. We found that the epitopes recognized by the antibodies $6 \mathrm{H} 9$ and $13 \mathrm{H} 4$ were formed, respectively, by sequences G113, W114, R120, Q122, Q123, A124, G125, Y130, S132, L133, N134, V189, W200 and W114, P119, R120, H126, I128, N129, Y130, S132, L133, N134, G135, W200 in the MRC fold. These epitopes contain approximately $50 \%$ identical AA and are localized in the region of the enzyme catalytic center. When delivered into live HeLa cells using cationic lipid- based PULSin reagent, specific antibodies against AMACR were co-localized with peroxisomes. The in-house made $6 \mathrm{H} 9$ antibody exhibited a low level of co-localization compared to the commercially available 63340 antibody, and did not inhibit the growth rate of HeLa and T98G cells. On the whole, we generated several clones of AMACR antibodies, and demonstrated that these antibodies can be colonized into live cells. Currently, we are testing the growth inhibitory properties of these antibodies.

\section{Materials and methods}

Animal care. A total of $5 \mathrm{BALB} / \mathrm{c}$ female mice (6-8 weeks old, weighing 20-22 g; The Jackson Laboratory, Bar Harbor, ME, USA) were used in all the experiments. The animals were maintained in the animal facility at the Northwestern University (Chicago, IL, USA). All experimental protocols were approved by the Institutional Animal Care and Use Committee at the Northwestern University.

Cell lines and cell culture. The LNCaP human prostate cancer cell line, C3H10T1/2 (10T1/2; mouse embryonic fibroblasts) and the SP-2/0 mouse myeloma cell line were obtained from the American Type Culture Collection (ATCC, Manassas, VA, USA); 293T cells, MCF7 breast carcinoma cells, HeLa cervical carcinoma cells, Caco 2 colon carcinoma cells and T98G human glioblastoma cells were obtained from the Culture Collection of the Institute of Cytology RAS (St. Petersburg, Russia). The Saos2 human osteosarcoma cells were kindly provided by Dr K. Helin (European Institute of Oncology, Milan, Italy). The cells were grown in Dulbecco's modified Eagle's medium (DMEM) with $10 \%$ fetal bovine serum (FCS) and gentamicin $(50 \mu \mathrm{g} / \mathrm{ml})$ in $\mathrm{a} \mathrm{CO}_{2}$ incubator under conditions of $5 \% \mathrm{CO}_{2}$ and $100 \%$ humidity.

Preparation of hybridomas producing monoclonal antibodies against AMACR: Induction and assessment of the immune response. The BALB/c female mice were immunized by intraperitoneal injections of $50 \mu \mathrm{g}$ of affinity purified recombinant AMACR in $150 \mu \mathrm{l}$ of sterile phosphate-buffered saline (PBS). As an adjuvant to the injection solution, $50 \mu \mathrm{g}$ of the oligonucleotide 5'-TCC-ATG-ACG-TTC-CTG-ACG-TT-3' were added (28). The injections were repeated 5 times at intervals of 2 weeks. At 7 days after the fourth injection, the animals were bled from the retro-orbital sinus for the detection in their serum the antibodies against AMACR by immunoblotting and enzyme-linked immunosorbent assay (ELISA) The bleeding was performed under anesthesia [xylazine $10 \mathrm{mg} / \mathrm{kg}+$ ketamine $80 \mathrm{mg} / \mathrm{kg}$ administered intraperitoneally (i.p.)].

Fusion of the immune splenocytes with mouse myeloma cells, HAT selection, screening, cloning of hybridomas and antibody isotyping. These procedures were carried out as previously described (29). The SP-2/0 myeloma cell line was passaged 1 day prior to fusion to yield $1 \times 10^{7}$ cells the following day. The cells were centrifuged for $5 \mathrm{~min}$ at, $200 \mathrm{x} \mathrm{g}$ at room temperature to remove FCS, resuspended in $10 \mathrm{ml}$ of DMEM/F12 without FCS and counted with $0.2 \%$ Trypan blue. Immune mouse spleen was removed under anesthesia as mentioned above 
followed by 5-7 min with euthanasia and cervical dislocation. The spleen was removed under sterile conditions and perfused with DMEM/F12 medium without FCS using a $21 \mathrm{G}$ needle with a $10 \mathrm{ml}$ syringe; the splenocytes were washed twice in $10 \mathrm{ml}$ of serum-free medium. For counting, $50 \mu \mathrm{l}$ of the cell suspension were mixed with $450 \mu \mathrm{l}$ of $1 \%$ acetic acid and then with $500 \mu 1$ of $0.2 \%$ Trypan blue in PBS. Subsequently, $7 \times 10^{7}$ splenocytes and $1 \times 10^{7}$ myeloma cells were mixed in a $50-\mathrm{ml}$ tube, washed once by centrifugation as described above, the supernatant was removed and the pellet was resuspended by tapping the tube. The cells were placed in a water bath at $37^{\circ} \mathrm{C}$, mixed with $1 \mathrm{ml}$ of warm $50 \%$ polyethylene glycol 1500 (Roche Diagnostics, Indianapolis, IN, USA) for $1 \mathrm{~min}$ with constant stirring of the slurry. Immediately thereafter, the cells were supplemented with $1 \mathrm{ml}$ of serum-free medium and then for 3-4 min with $3 \mathrm{ml}$ of serum-free medium followed by the addition of $20 \mathrm{ml}$ of serum-free medium and $20 \mathrm{ml}$ of medium with $15 \%$ FCS. The cells were incubated for $30 \mathrm{~min}$ at $37^{\circ} \mathrm{C}$, pelleted at $200 \mathrm{x}$ g resuspended in $42 \mathrm{ml}$ of DMEM/F12 with $15 \%$ FCS and 10\% BM-Condimed H1 (Roche Diagnostics), 1X HAT (Roche Diagnostics), and cultured at 5 x 96-well plates of $100 \mu 1$ per well. After 7 days, the growth medium was exchanged with HAT-free medium. Within 3 days, the hybridomas were screened for antibody production by ELISA. The cells in the wells with positive reaction were cloned by inoculating 100 cells in 96-well plates and the supernatants were screened for antibody production. Cloning was continued until all clones did not exhibit a positive reaction.

Monoclonal antibody isotyping. Antibody isotyping was performed using the mouse hybridoma subisotyping kit purchased from Calbiochem (La Jolla, CA, USA) according to the manufacturer's recommendations. Brifly, separate wells of a 96-well ELISA plate were sequentially filled with the goat anti-mouse IgGs, blocking solution, an the hybridoma supernatants were diluted 10 -fold, isotyping antisera were added, and the wells were then visualized by TMB reagent and read at OD450 $\mathrm{nm}$.

Detection of phage peptide mimotopes recognized by antibodies against AMACR. Phage peptide sequences specifically recognized by in-house made murine (clones 6H9 and 2A5) and the commercial rabbit monoclonal (clone 13H4; Zeta Corp., Arcadia, CA, USA) antibody against AMACR (mimotopes), were determined using a commercial phage peptide library Ph.D.-7C7 (BioLabs) based on combinatorial plurality of random 7-mer peptides fused to the pIII coat protein of M13 phage (30). In this library, the randomize peptide sequence is flanked by a pair of cysteine residues. Under non-reducing conditions, the cysteines form a disulfide crosslink, resulting in the phage display of cyclized peptides. The library consists of $1.2 \times 10^{9}$ sequences amplified to produce 200 copies of each sequence in $10 \mu \mathrm{l}$ of the phage library.

Biopanning with antibodies in solution. The selection of phage particles containing mimotopes (biopanning), was performed by incubating the antibodies coupled to protein A/G immobilized on agarose beads (Pierce, Rockford, IL, USA). The E. coli ER2738 cells (included in the Ph.D.-7C7 BioLabs kit) were grown in $5 \mathrm{ml}$ of LB medium on a shaker at $37^{\circ} \mathrm{C}$ until early logarithmic phase (OD600 to 0.01-0.05) for titration and at the same time in $20 \mathrm{ml}$ of LB medium for the amplification of phage particles. Subsequently, $50 \mu \mathrm{l}$ of $50 \%$ protein A-agarose was resuspended in $1.5 \mathrm{ml}$ microtube in $1 \mathrm{ml}$ of TBST [10 mM Tris- $\mathrm{Cl}$ (pH 8.0), $150 \mathrm{mM} \mathrm{NaCl}, 0.1 \%$ Tween-20] and precipitated. The precipitate was washed in TBST by 3-fold centrifugation for $5 \mathrm{~min}$ at 2,000 $\mathrm{x}$ g. Protein A-agarose was resuspended in $1 \mathrm{ml}$ of blocking buffer $[0.1 \mathrm{M}$ $\mathrm{NaHCO}_{3}(\mathrm{pH} 8.6), 5 \mathrm{mg} / \mathrm{ml}$ bovine serum albumin (BSA), $0.02 \% \mathrm{NaN}_{3}$ ], incubated for $60 \mathrm{~min}$ at $4^{\circ} \mathrm{C}$ followed by stirring. Subsequently, $10 \mu \mathrm{l}$ of the phage library in suspension $\left(2 \times 10^{11}\right.$ $\mathrm{Pfu}$ ) and $300 \mathrm{ng}$ of anti-AMACR antibodies were mixed in $200 \mu \mathrm{l}$ of TBST, incubated for $20 \mathrm{~min}$ at room temperature, transferred to a $1.5 \mathrm{ml}$ tube containing the affinity sorbent, incubated for $15 \mathrm{~min}$ at room temperature with irregular stirring and centrifuged for $5 \mathrm{~min}$ at 2,000 $\mathrm{x} \mathrm{g}$ at room temperature. The supernatant was removed and the sorbent was washed 10 times in $1 \mathrm{ml}$ of TBST and precipitated by centrifugation as described above. The phage particles bound to protein A-agarose were eluted for $10 \mathrm{~min}$ at room temperature in $1 \mathrm{ml}$ of $0.2 \mathrm{M}$ glycine- $\mathrm{HCl}(\mathrm{pH} 2.2)$ containing $1 \mathrm{mg} / \mathrm{ml} \mathrm{BSA}$. The eluate was centrifuged for $1 \mathrm{~min}$ at $13,000 \mathrm{x} \mathrm{g}$, the supernatant was transferred to a new microtube, neutralized by adding of $150 \mu \mathrm{l}$ of $1 \mathrm{M}$ Tris- $\mathrm{HCl}(\mathrm{pH} 9.1)$ and titrated on plates containing LB agar with isopropyl- $\beta$-D-1-thiogalactopyranoside (IPTG) and 5-bromo-4-chloro-3-indolyl- $\beta$-D-galactopyranoside (X-Gal). The eluted phage particles were amplified in $20 \mathrm{ml}$ of ER2738 cell culture in the logarithmic growth phase and incubated at $37^{\circ} \mathrm{C}$ for $4-5 \mathrm{~h}$ on a shaker. The culture of the bacterial cells was centrifuged the following day for $10 \mathrm{~min}$ at $13,000 \times \mathrm{g}$ and $4^{\circ} \mathrm{C}$, the supernatant was transferred to new tube, and centrifugation was repeated; $80 \%$ of the top layer of supernatant was transferred to new tube, followed by the addition of a $1 / 6$ volume of $20 \%$ polyethylene glycol (PEG) 8000 , containing $2.5 \mathrm{M} \mathrm{NaCl}$; the solution was left for $2 \mathrm{~h}$ at $4^{\circ} \mathrm{C}$, the precipitate was spun down for $15 \mathrm{~min}$ at $13,000 \mathrm{x} \mathrm{g}$ and $4^{\circ} \mathrm{C}$, the pellet was resuspended in $1 \mathrm{ml}$ of TBS [50 mM Tris- $\mathrm{Cl}$ ( $\mathrm{pH} 7.5$ ), $150 \mathrm{mM} \mathrm{NaCl}, 0.2 \% \mathrm{NaN}_{3}$ ], centrifuged for $1 \mathrm{~min}$ at $13,000 \mathrm{xg}$, and the supernatant was transferred to a new tube and titrated on plates with LB/IPTG/X-Gal using the predicted titer levels of $10^{-8}-10^{-11} \mathrm{Pfu}$. To do that, $200 \mu \mathrm{l}$ of bacterial cultures in microtubes were supplemented with $10 \mu \mathrm{l}$ of phage particles in each dilution for 1-5 min, the infected cells were transferred to tubes containing $3 \mathrm{ml}$ of warmed up to $45^{\circ} \mathrm{C}$ agarose, mixed and applied as the upper layer on the cup agar plates containing IPTG/X-Gal; the plates were cooled for $5 \mathrm{~min}$, inverted and incubated overnight at $37^{\circ} \mathrm{C}$. The following day, the numbers of blue colonies were counted and the phage titer was determined using as a baseline titer of $2 \times 10^{11} \mathrm{Pfu}$. During the course of second round of phage concentration, we used protein G-instead of protein A-agarose and the Tween-20 concentration in TBST was increased up to $0.5 \%$. During third round of phage selection, we used protein A-agarose and $0.5 \%$ Tween-20 for washing. Finally, the phage particles from 10 different colonies were transferred and amplified in separate tubes using overnight culture of the ER2738 cells for $4-5 \mathrm{~h}$ at $37^{\circ} \mathrm{C}$. The bacterial cultures were then transferred to microtubes, centrifuged for $30 \mathrm{sec}$ at $13,000 \times \mathrm{g}$ at $+4^{\circ} \mathrm{C}, 500 \mu \mathrm{l}$ of upper layer of the supernatant was transferred into new tube, supplemented with $200 \mu \mathrm{l}$ of 
PEG/NaCl, and the tube content was mixed by inverting and left at room temperature for $10 \mathrm{~min}$, centrifuged for $10 \mathrm{~min}$ at $13,000 \mathrm{xg}$; the supernatant was removed, the pellet was resuspended in $100 \mu \mathrm{l}$ of the buffer containing iodide chloride [10 mM Tris- $\mathrm{Cl}$ (pH 8.0), 1 mM EDTA, 4M ICl], supplemented with $250 \mu \mathrm{l}$ of ethanol for $10 \mathrm{~min}$ at room temperature and spun down for $10 \mathrm{~min}$; the supernatant was removed, the pellet was washed with $70 \%$ ethanol, dried and diluted in $30 \mu \mathrm{l}$ of deionized water. The phage DNA was sequenced using dyelabeled dideoxynucleotides in the Sequencing Facility of the Northwestern University (Chicago, IL, USA).

Antibody epitope mapping. This was performed using the program Pepitope available online (http://pepitope.tau.ac.il) (26), the algorithm PepSurf (27) and the crystal structure of MRC, PDB 1x74 (1).

ELISA. In total, $100 \mu \mathrm{l}$ of recombinant AMACR or BSA as a negative control $(10 \mu \mathrm{g} / \mathrm{ml})$ in $0.05 \mathrm{M}$ sodium carbonate buffer ( $\mathrm{pH}$ 9.6) were added into 1 well of a 96-well plate for ELISA for $3 \mathrm{~h}$ at room temperature or overnight at $+4^{\circ} \mathrm{C}$. Unbound material was removed by washing 3 times with PBST buffer (PBS containing 0.05\% Tween-20). The unbound sites were saturated with the addition of $3 \%$ BSA in PBST for $1 \mathrm{~h}$. The plate was washed 3 times with PBST and $100 \mu \mathrm{l}$ of hybridoma supernatant, and diluted mouse immune serum or BSA were added into 1 well for $1 \mathrm{~h}$ at room temperature. The plate was then washed as described above and $100 \mu \mathrm{l}$ of anti-mouse-HRP antibody was loaded into each well for $1 \mathrm{~h}$ at room temperature. To visualize peroxidase staining, $100 \mu \mathrm{l}$ of tetramethylbenzidine (TMB) substrate (Sigma-Aldrich, St. Louis, MO, USA) containing $0.01 \%$ hydrogen peroxide for 5-30 min were added into each well. TMB was prepared from the $1 \mathrm{mg} / \mathrm{ml}$ stock solution diluted $1: 100$ by $0.1 \mathrm{M}$ sodium acetate buffer. The reaction was terminated by the addition of $50 \mu \mathrm{l}$ of $10 \%$ phosphoric acid and the absorbance was read at $450 \mathrm{~nm}$ using a Dynex MRC TC Revelation microplate reader (Dynex Technologies, Inc., Chantilly, VA, USA).

Immunofluorescence staining. Intracellular proteins were stained as follows: coverslips with spread cells grown in culture or attached to the glass as a result of close contact with sections of various mouse organs (kidneys, liver, heart, bladder and thymus, which were obtained under the conditions described above in the section entitled 'Animal care') were placed in 35-mm plates, washed with PBS for 5 min, fixed with 4\% paraformaldehyde for $15 \mathrm{~min}$, and then with $70 \%$ ethanol overnight at $4{ }^{\circ} \mathrm{C}$, treated with $0.2 \%$ Triton $\mathrm{X}-100$ for $10 \mathrm{~min}$ and washed with PBS twice for $5 \mathrm{~min}$. Unspecific binding was blocked by $3 \%$ BSA with $0.1 \%$ Tween-20 for $1 \mathrm{~h}$. The cells were incubated with primary antibodies (rabbit monoclonal anti-AMACR, cat. no. 13H4; Zeta Corp., Sierra Madre, CA, USA; mouse monoclonal anti-AMACR, cat. no. ab63340; Abcam, Cambridge, UK; in-house made mouse monoclonal antibodies against AMACR 6H9 and 2A5; antibody dilutions were 1:50-1:200) in blocking solution for $1 \mathrm{~h}$ at room temperature, washed 3 times with PBS for $5 \mathrm{~min}$ and incubated with labeled species-specific antibodies [Cy3 goat anti-mouse $\mathrm{IgG}$ $(\mathrm{H}+\mathrm{L})$, cat. no. A10521; and Cy5 goat anti-rabbit $\operatorname{IgG}(\mathrm{H}+\mathrm{L})$, cat. no. A10523, both from Molecular Probes, Eugene, OR,
USA], washed 3 times with PBS for 5 min and mounted in Anti-Fade (Bio-Rad Laboratories, Hercules, CA, USA) containing DAPI for nuclei staining. Images were recorded on Leica TCS SP5 (Leica Microsystems, Wetzlar, Germany) or Olympus FV3000 (Olympus, Tokyo, Japan) confocal scanning microscopes using lasers at a 405, 488 and $561 \mathrm{~nm}$ wavelength.

Protein electrophoresis and immunoblotting. Protein electrophoresis and immunoblotting were performed as previously described (31). Electrophoresis was run on $8 \%$ SDS-PAGE on mini or large vertical protein electrophoresis chambers (BioRad Laboratories). The probes for SDS-PAGE were prepared from human prostate tissues and cells of established cell lines. The prostate tissues were obtained from 5 male cancer patients, 60-70 years of age, subjected to radical prostatectomy in accordance with the procedure approved by the Ethics Committee of the Northwestern University Review Board (IRB) protocol. All patients provided written informed consent. The prostate tissue probes included 5 samples of tumors and 4 samples of normal tissues adjacent to the tumors obtained from the same patients.

Tissue samples of approximately $10 \mathrm{mg}$ were placed in tubes with $100 \mu \mathrm{l}$ of lysis buffer containing 1\% SDS, $50 \mathrm{mM}$ TrisCl (pH 6.8), $100 \mathrm{mM} \beta$-mercaptoethanole, protease and phosphatase inhibitor cocktails (Sigma-Aldrich); treated with Cole-Parmer 130 Watt Ultrasonic Processor (Cole-Parmer, Vernon Hills, IL, USA) with $70 \%$ amplitude 6 times for $10 \mathrm{sec}$, incubated for $0^{\circ} \mathrm{C}$ for $20 \mathrm{~min}$, and centrifuged at $13,000 \mathrm{x}$ g for 15 min at $+4^{\circ} \mathrm{C}$.

The cells grown on culture plates were washed twice with PBS and removed with a plastic scrapper, sedimented by centrifugation as described above and lysed with periodic resuspending on ice for $30 \mathrm{~min}$ in 3 volumes (relative to the volume of the dense cellular pellet) of buffer solution composed of $25 \mathrm{mM}$ Tris- $\mathrm{HCl}$ (pH 7.4), $250 \mathrm{mM} \mathrm{NaCl}, 0.25 \%$ NP-40, protease and phosphatase inhibitor cocktails in 1:100 dilution. Cellular extracts were centrifuged at 13,000 x g for $15 \mathrm{~min}$ at $4^{\circ} \mathrm{C}$. Supernatants were applied for further experiments. The probes were equilibrated for protein content determined by Bradford reagent (Bio-Rad Protein Assay kit II, cat. no. 5000002; Bio-Rad Laboratories), transferred to microtubes with an equal volume of loading buffer [5\% SDS, 20\% glycerol, $200 \mathrm{mM}$ dithiotreitol, $120 \mathrm{mM}$ Tris- $\mathrm{HCl}$ (pH 6.8), $0.002 \%$ bromophenol blue] and boiled for $5 \mathrm{~min}$ in a water bath. Probes in the volume of $25 \mu \mathrm{l}$ containing 30-90 $\mu \mathrm{g}$ of total protein were loaded on one line of polyacrylamide gel. Electrophoretically separated proteins were transferred onto a PVDF membrane by semi-dry electrotransfer. The proteins on the membrane were revealed using specific antibody against AMACR described above and secondary Peroxidase AffiniPure goat anti-mouse IgG $(\mathrm{H}+\mathrm{L})$ (cat. no. 115-035-003; Jackson ImmunoResearch Laboratories, Inc., West Grove, PA, USA) and anti-rabbit IgG, HRP-linked antibody, cat. no. 7074S; Cell Signaling Technology, Danvers, MA, USA) and visualized with ECL ${ }^{\mathrm{TM}}$ Western Blotting Detection Reagent (cat. no. RPN2209; Sigma-Aldrich).

AMACR immunoprecipitation assay. To evaluate the ability of the anti-AMACR antibody to immunoprecipitate (IP)-specific antigen, we first prepared the affinity matrix. Two $1.5 \mathrm{ml}$ 
Eppendorf microtubes were loaded with $50 \mu \mathrm{l}$ of $50 \%$ protein G-sepharose (Invitrogen, Carlsbad, CA, USA), washed 5 times with $0.5 \mathrm{ml}$ of PBS and supplemented with $1.25 \mathrm{ml}$ of the serum-free hybridoma supernatant containing anti-AMACR antibody $6 \mathrm{H} 9$ or with $2 \mu \mathrm{l}$ of the immune serum from an immunized with AMACR mouse in $1.25 \mathrm{ml}$ of PBS. The supernatant was prepared using ex-cell 610-HSF hybridoma serum-free medium (SAFC Biosciences, Lenexa, KS, USA). The microtubes were rotated for $1.5 \mathrm{~h}$ at room temperature to couple the antibody to protein G-sepharose and washed 5 times with the IP buffer containing $25 \mathrm{mM}$ TrisCl ( $\mathrm{pH} 7.5)$, $50 \mathrm{mM} \mathrm{NaCl}, 0.2 \%$ SDS, $1 \%$ NP-40, protease and phosphatase inhibitor cocktails in 1:100 dilution. The prepared affinity matrix was loaded with extracts from mouse liver containing 0.5-2 $\mathrm{mg}$ of total protein. The tubes with IP were rotated overnight at $4{ }^{\circ} \mathrm{C}$ to couple the AMACR protein from the cell extracts to protein G-sepharose, the affinity matrix was washed 5 times with the IP buffer and twice with the same buffer without detergents. After a final washing, the tubes containing the immune complexes were loaded on $25 \mu \mathrm{l}$ of SDS-PAGE loading buffer, boiled for $5 \mathrm{~min}$ and centrifuged for $5 \mathrm{~min}$ at $13,000 \mathrm{x}$. The supernatants were loaded into $10 \%$ polyacrylamide gel to separate proteins under reducing conditions. The separated proteins were transferred from gel onto a PVDF membrane and visualized with ECL as described above.

Affinity purification. The $6 \mathrm{H} 9$ and 2A5 hybridoma supernatants were prepared by growing the cells for 15 days in Ex-Cell 610-HSF hybridoma serum-free medium in CELLine 1000 flasks (Integra Biosciences, Hudson, NH, USA). The supernatants were spun down for $30 \mathrm{~min}$ at 2,000 x g, filtered through a $0.45-\mu \mathrm{m}$ filter and evaluated for protein concentration and antibody activity by ELISA and immunoblotting. For affinity purification, the supernatants were loaded into a $1 \mathrm{ml}$ protein G-column (HiTrap Protein G HP; GE Healthcare Life Sciences, Pittsburgh, PA, USA) equilibrated with 3 column volumes of binding buffer (0.02 M sodium phosphate, $\mathrm{pH} 7.0$ ). The column was washed with 10 column volumes of the binding buffer to remove impurities and unbound material. The bound antibody was eluted with $1 \mathrm{ml}$ of elution buffer $(0.1 \mathrm{M}$ glycine- $\mathrm{HCl}, \mathrm{pH} 2.7$ ) into a microtube containing $100 \mu \mathrm{l}$ of neutralization buffer (1 M Tris- $\mathrm{HCl}, \mathrm{pH}$ 9.0). To exchange the elution buffer, $200 \mu \mathrm{l}$ of the sample was loaded on a Zeba Spin $0.5 \mathrm{ml}$ desalting column (Thermo Fisher Scientific, Waltham, MA, USA). Prior to desalting, the column was washed 3 times by centrifugation with $300 \mu \mathrm{l}$ of PBS for $1 \mathrm{~min}$ at $1,500 \mathrm{x} \mathrm{g}$. Subsequently, $200 \mu 1$ of the eluate was applied on the top of the resin and supplemented with $15 \mu \mathrm{l}$ of the stacker. The sample recovery was performed by spinning at 1,500 x g for $2 \mathrm{~min}$, and the protein concentration was estimated by Bradford assay.

Antibody delivery into cells and estimation of their growth curves and proliferation rate. Antibody delivery into cells was performed using PULSin reagent (Polyplus-transfection Inc., New York, NY, USA). Subsequently, 6 wells of a 24-well plate were loaded with cover glasses (one 8-mm glass into each well) and seeded with $2 \times 10^{5}$ exponentially growing HeLa or T98G cells in DMEM containing $10 \%$ FCS. The following day, when the cell saturation density was $70-80 \%$, the cells were washed twice with PBS and the growth medium in wells was exchanged to $900 \mu \mathrm{l}$ of DME serum-free medium. Three master mixes were prepared: i) $250 \mu \mathrm{l}$ of $20 \mathrm{mM}$ HEPES buffer ( $\mathrm{pH} 7.4$ ) and $2 \mu \mathrm{g}$ of the non-specific $2 \mathrm{~A} 5$ antibody; ii) $250 \mu \mathrm{l}$ of $20 \mathrm{mM}$ HEPES buffer (pH 7.4) and $2 \mu \mathrm{g}$ of the specific $6 \mathrm{H} 9$ antibody against AMACR; iii) $250 \mu \mathrm{l}$ of $20 \mathrm{mM}$ HEPES buffer (pH 7.4) and $2 \mu \mathrm{g}$ of the specific 63340 antibody against AMACR purchased from Abcam (Cambridge, UK). The mixes were filtered and supplemented with $5 \mu \mathrm{l}$ of PULSin reagent (Polyplus-transfection Inc.) for $15 \mathrm{~min}$ at room temperature. Each mixture was then divided in two and added to the wells with the HeLa or T98G cells. Following $4 \mathrm{~h}$ of incubation at $37^{\circ} \mathrm{C}$, the growth medium was exchanged with fresh one containing $10 \%$ FCS and the cells were kept in a $\mathrm{CO}_{2}$ incubator overnight. The following day, the adherent cells on coverglasses were stained with anti-mouse antibody conjugated with Cy3 dye (Invitrogen). In the case of effective proteofection ( $\geq 80 \%$ exhibited positive immunofluorescence with specific anti-AMACR antibody), the cells were trypsinized, washed, counted and seeded into 15 wells of a 96-well plate at a density of $2 \times 10^{4}$ cells per well in $100 \mu \mathrm{l}$ of culture medium. For growth curves, the number of cells was evaluated in triplicate each day for the following 5 days using counting chambers.

The proliferation rate was estimated using the Cell Proliferation kit I MTT (Sigma-Aldrich) according to the manufacturer's instructions. The cells treated with the antibodies were seeded at a concentration of $5 \times 10^{3}$ cells/well in $100 \mu \mathrm{l}$ culture medium in 9 wells of a 96 -well plate and incubated for $24 \mathrm{~h}$. After the incubation period, $10 \mu \mathrm{l}$ of MTT labeling reagent (Cell Proliferation kit, REF 11465007001; Roche Diagnostics, GmbH, Mannheim, Germany) were added to each well and the cells were placed into a $\mathrm{CO}_{2}$ incubator for $4 \mathrm{~h}$. Subsequently, $100 \mu \mathrm{l}$ of the solubilization solution were added to each well and the plate was incubated overnight in a $\mathrm{CO}_{2}$ incubator followed by measuring the optical density (OD) at $570 \mathrm{~nm}$ using an ELISA reader (Fluorofot; Probanauchpribor LLC, St. Petersburg, Russia).

Estimation of co-localization of antibody to AMACR delivered into cells and peroxisome labeled with fluorescent dye. The HeLa or T98G cells were labeled with CellLight Peroxisome-GFP, BacMam 2.0 reagent (Molecular Probes, Eugene OR, USA) as follows: The cells asynchronously growing on $60-\mathrm{mm}$ cell culture with $70 \%$ density were supplemented with $10 \mu \mathrm{l}$ of CellLight reagent (10 particles per cell) for $18 \mathrm{~h}$. Co-localization was evaluated the following day after staining the cells with mouse monoclonal antibodies to AMACR (ab63340; Abcam, in-house made 6H9) and antimouse antibody coupled to $\mathrm{Cy} 3$ as described above. For the study of peroxisome co-localization with AMACR detected by the antibody delivered into live cells, the cells with labeled peroxisomes were transferred into the wells of a 24-well plate containing coverglasses and proteofected the following day as described above. Immunofluorescence was visualized using an Olympus FV3000 fluorescence confocal microscope (Olympus) with 405, 488 and $561 \mathrm{~nm}$ lasers.

Statistical analysis. Statistical analysis was performed using Microsoft Excel 2010 software. Each experiment was repeated at least 3 times. 
A

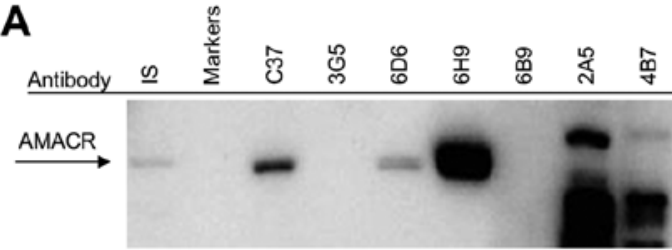

C

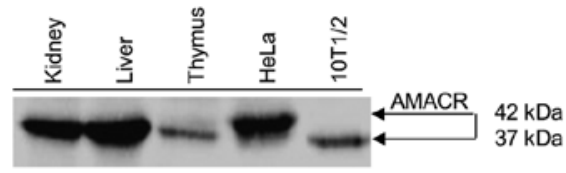

B

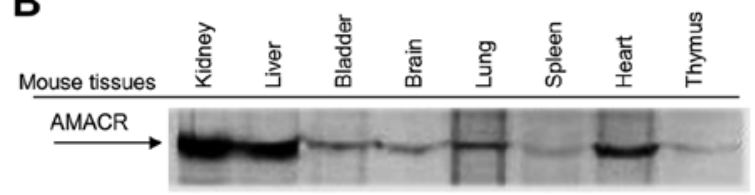

D

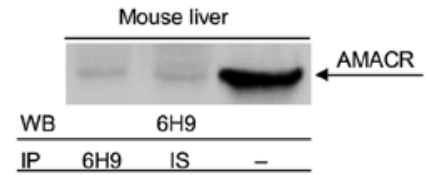

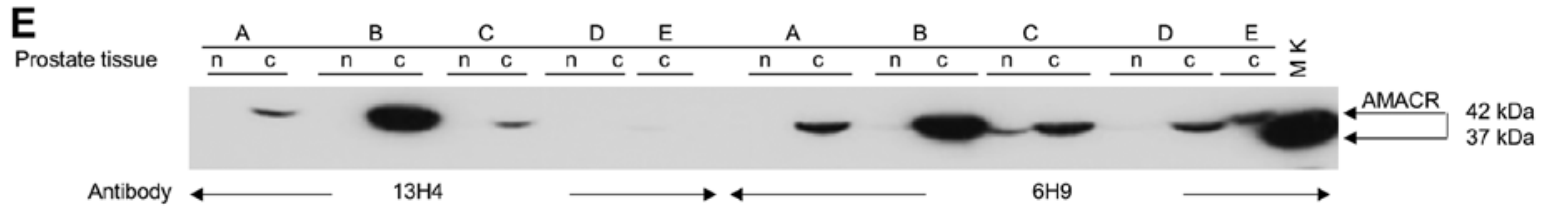

Figure 1. Comparative evaluation of specific activity of the in-house made and commercial monoclonal antibodies against AMACR. (A) Immunoblot characterization of monoclonal antibodies against AMACR. A total of $30 \mu \mathrm{g}$ of total protein from extract of the LNCaP human prostate cell line was used for one line of $8 \%$ SDS-PAGE gel; IS, immune serum of the mouse donor splenocytes used for preparation of the $6 \mathrm{H} 9$ hybridoma. (B) The steady-state levels of AMACR in various mouse tissues; immunoblotting with in-house made $6 \mathrm{H} 9$ antibodies, $30 \mu \mathrm{g}$ of total protein from extracts of various mouse tissues was used for one line of SDS-PAGE gel. (C) Comparative evaluation of AMACR production in various human and mouse tissues and cell lines using 6H9 antibody. (D) Evaluation of the immunoprecipitation ability of the $6 \mathrm{H} 9$ antibody. WB, western blotting (immunoblotting); IP, immunoprecipitation; IS, immune serum of the mouse donor splenocytes used for the preparation of the $6 \mathrm{H} 9$ hybridoma. (E) Site-by-site immunoblotting comparative analysis of AMACR detection by in-house made $6 \mathrm{H} 9$ and commercial 13H4 antibodies. A total of $50 \mu \mathrm{l}$ of extract containing $90 \mu \mathrm{g}$ of total protein from tumor (c) or normal (n) prostate tissues of patients with prostate cancer was loaded on one line of $8 \%$ SDS-PAGE in duplicate, the separated proteins were transferred onto a PVDF membrane, the left half of the blotted material was treated with commercial $13 \mathrm{H} 4$ antibody, and the right part with in-house made6H9 antibody; the proteins were visualized on a PVDF membrane with ECL reagent; MK, extract of mouse kidney.

\section{Results}

Preparation and characterization of monoclonal antibodies against AMACR. The immunization of mice with recombinant human AMACR and adjuvant oligonucleotide comprising the $\mathrm{CpG}$ residues caused a rapid and strong immune response. In 1 week after the fourth intraperitoneal injection of the antigen, the antibodies which recognized AMACR were clearly detected in the mouse serum diluted 1:4,000 were by ELISA and immunoblotting (Fig. 1A). In the result of the fusion of the immune splenocytes and myeloma cells followed by HAT selection and screening by ELISA, we selected 20 hybridomas producing antibodies which showed the signal exceeding 1.0 standard unit at $450 \mathrm{~nm}$ ( $>50 \%$ of the full scale value). In total, 5 of the 20 hybridomas produced antibodies of the IgG1 isotype, 4 of the $\operatorname{IgG} 2 b$ isotype and 11 of the $\operatorname{IgM}$ isotype. The antibodies secreted by 4 different hybridomas bound the 1A AMACR isoform in both extracts from the mouse kidney (37 kDa) and human prostate cell line LNCaP (42 kDa), as shown by immunoblotting; the remaining 16 antibodies did not bind any protein or interacted with several proteins The blots in Fig. 1A shows that 3C7, 6D6, 6H9 antibodies bound a $42 \mathrm{kDa}$ protein, 3G5, 6B9 do not recognize any protein, while $2 \mathrm{~A} 5$ and $4 \mathrm{~B} 7$ recognize several non-specific proteins in immunoblotting. For the following experiments, we selected $6 \mathrm{H} 9$ antibody which a specifically recognized $1 \mathrm{~A}$ isoform of AMACR and 2A5 non-specific antibody as a negative control for $6 \mathrm{H} 9$.

Evaluation of AMACR expression in various tissues and cell lines of mouse and human origin by the in-house made mono- clonal antibodies. We found that in-house made antibody which bound AMACR in extracts of $\mathrm{LNCaP}$ human prostate cells (Fig. 1A), also recognized this antigen by immunoblotting in various mouse tissues. The highest levels of AMACR expression were detected in the kidney, liver and heart; however, in the bladder, brain, spleen and thymus, the antibody bound small amounts of the protein (Fig. 1B). Human HeLa cells exhibited the high levels of AMACR production similar to mouse liver and kidney tissues; however, human AMACR migrated as a $42 \mathrm{kDa}$ band, while all mouse tissues contained the $37 \mathrm{kDa}$ AMACR isoform (Figs. 1C and 2B). In immunoprecipitation assay, the antibody to AMACR similar to the immune serum of mouse-donor splenocytes used for hybridoma production bound minimal amounts of AMACR from mouse liver in contrast to the high levels of this protein detected by this antibody in immunoblotting (Fig. 1D). These results were confirmed by immunofluorescence staining of the mouse tissues performed with the $6 \mathrm{H} 9$ antibody (Fig. 2A). The cell lines of human origin, similar to the mouse tissues, exhibited a distinct AMACR expression dependent on their tissue origin. AMACR was highly expressed in HeLa cervical carcinoma and $\mathrm{Caco} 2$ colon carcinoma cells, in contrast to MCF7 breast carcinoma, 293T and Saos2 osteosarcoma cells (Fig. 2B). To compare the specific activity of the in-house made $6 \mathrm{H} 9$ and commercial antibody, $13 \mathrm{H} 4$, we performed a site-by-site immunoblot comparison of AMACR detection in probes from cancer or normal prostate tissue from patients with prostate cancer. This experiment revealed that the in-house made antibody, $6 \mathrm{H} 9$, possessed a higher antigen sensitivity and detected AMACR in all 5 probes from the cancer tissue of the patients with prostate cancer compared 

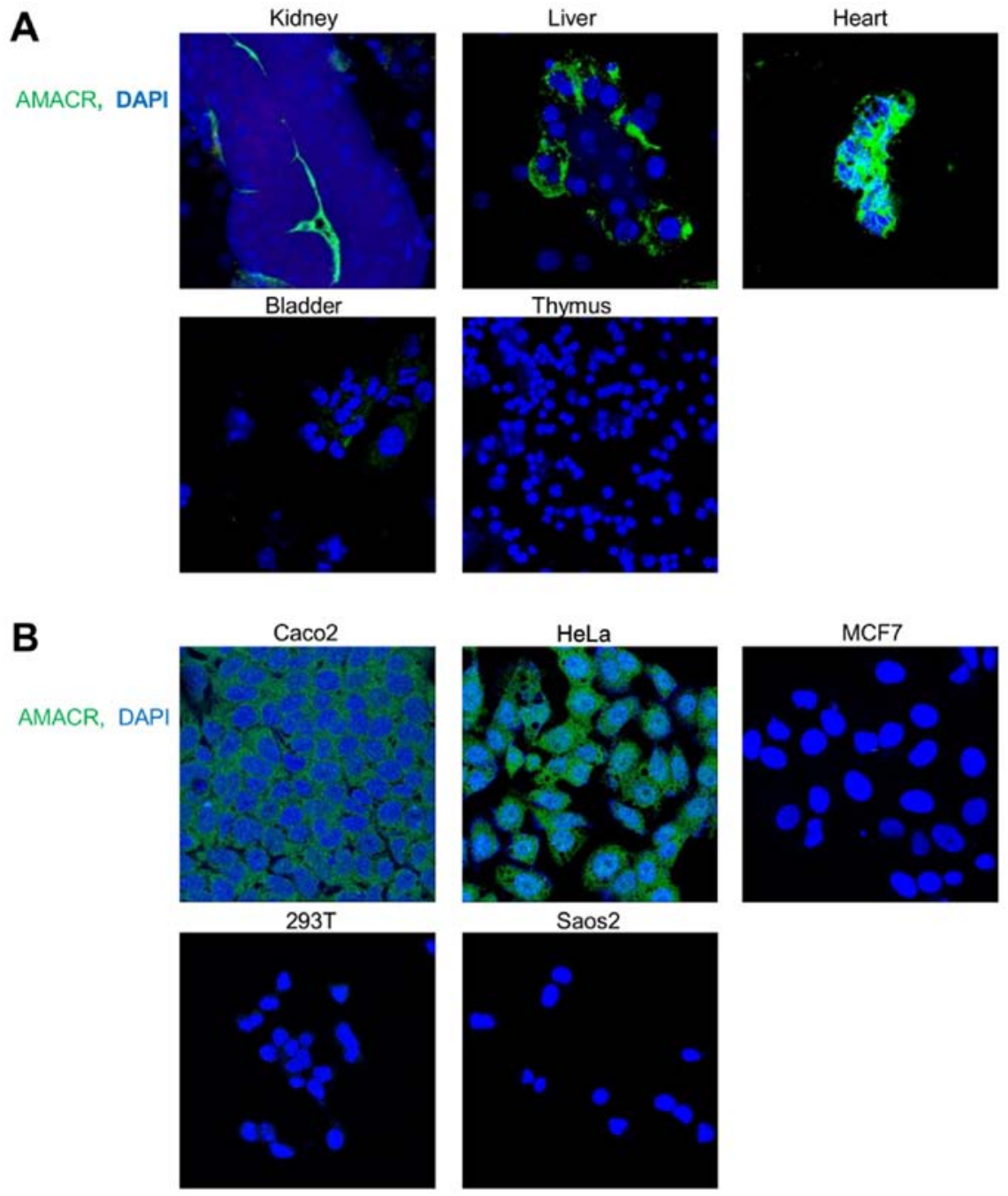

Figure 2. Immunofluorescence evaluation of AMACR production in (A) various mouse tissues and (B) human established cell lines by $6 \mathrm{H} 9$ antibody. (A) Mouse kidney, liver and heart exhibited significant AMACR levels, whereas mouse bladder and thymus did not exhibit any detected levels of AMACR. Established human cell lines exhibited a distinct AMACR expression. AMACR was highly expressed in Caco2 colon carcinoma and HeLa cervical carcinoma cells in contrast to the undetectable AMACR levels in MCF7 breast carcinoma, 293T and Saos2 osteosarcoma cells. Images were prepared using a confocal scanning microscope (Leica TCS SP5), lasers 405 and $488 \mathrm{~nm}$, with a X40 objective; the size of the images is $192 \mu \mathrm{m}$. Positive staining is shown in green.

with 3 from 5 probes detected by the commercial antibody, 13H4 (Fig. 1E).

Identification and characterization of phage mimotopes recognized by the antibodies against AMACR. The antibodies, $6 \mathrm{H} 9$, $2 \mathrm{~A} 5$ and $13 \mathrm{H} 4$, demonstrated a high and reproducible signal in ELISA; however, they yielded different images of antigen binding in immunoblotting. The $6 \mathrm{H} 9$ and $13 \mathrm{H} 4$ antibodies recognized the $42 \mathrm{kDa} 1 \mathrm{~A}$ human AMACR isoform, while the 2A5 antibody bound several proteins with different molecular mass (MM) (Fig. 1A). Given the differences in the characteristics of the antibody/antigen interaction in immunoblotting, we used the 2A5 antibody as a negative control. Sequencing of the phage DNA from 10 different clones obtained by biopanning and subsequent translation of the phage DNA revealed that the $6 \mathrm{H} 9$ and $13 \mathrm{H} 4$ antibodies bound the same AA sequence in 7 and 5 out of 10 cases, respectively. By contrast, the 2A5 antibody recognized 10 different mimotopes in biopanning (Table I).

Mapping of 10 phage mimotopes selected with the $6 \mathrm{H} 9$ antibody revealed 3 clusters on the the surface of MRC, the
AA sequences, in which most closely corresponded to those in the phage polypeptides. In accordance with the program, the most possible conformational epitope (probability is 89.112 conventional units) recognized by this antibody included AA G113, W114, R120, Q122, Q123, A124, G125, Y130, S132, L133, N134, V189 and W200 of MRC. This epitope was homologous to the phage mimotopes LKWGVHW and LKYGQHR, identified, respectively, at 7 and 1 of the 10 phage clones (Table I). To find the epitope recognized by the $13 \mathrm{H} 4$ antibody, we used sequences of 9 phage mimotopes (mimotope KSLPXHS contains an unspecified residue and was not included in the analysis). In total, 3 clusters of AA were found for this antibody among which the greatest homology (46.293 conventional units) showed the sequence which included W114, P119, R120, H126, I128, N129, Y130, S132, L133, N134, G135 and W200 of MRC. This epitope was homologous to polypeptides WWWSLQP and HKSLGTW, identified, respectively, in 5 and 1 from 9 phage clones (Table I). Antibody 2A5 interacted with 10 different mimotopes, from which the sequences FPTFPNQ, TPSNKHT, NNILPMT, PWGFPYK revealed the greatest degree of homology (probability is 37.089 conven- 
Table I. Characterization of the phage mimotopes and corresponding epitopes in MRC, human and mouse AMACR recognized by the $6 \mathrm{H} 9,13 \mathrm{H} 4$ and $2 \mathrm{~A} 5$ antibodies.

\begin{tabular}{|c|c|c|c|c|c|c|c|c|c|c|}
\hline \multirow{2}{*}{$\frac{\text { Antibodies }}{6 \mathrm{H} 9}$} & \multicolumn{7}{|c|}{$\begin{array}{l}\text { Phage mimotopes and their } \\
\text { homologs in MRC, human } \\
\text { and mouse AMACR }\end{array}$} & \multirow[t]{2}{*}{$\begin{array}{l}\text { Number of fully } \\
\text { identical mimotopes } \\
\text { in } 10 \text { selected phage }\end{array}$} & \multirow[t]{2}{*}{$\begin{array}{l}\text { Number of } \\
\text { identical AA }\end{array}$} & \multirow[t]{2}{*}{$\begin{array}{c}\text { Number of } \\
\text { conservative AA }\end{array}$} \\
\hline & & & & & & & & & & \\
\hline Mimotope \# 1 & $\mathrm{~L}$ & $\mathrm{~K}$ & $\mathrm{~W}$ & $\mathrm{G}$ & $\mathrm{V}$ & $\mathrm{H}$ & $\mathrm{W}$ & $7 / 10$ & & \\
\hline MRC & $\mathrm{L}$ & $\mathrm{R}$ & $\mathrm{W}$ & $\mathrm{G}$ & $\mathrm{V}$ & $\mathrm{N}$ & $\mathrm{W}$ & & 5 & 5 \\
\hline PGAA & 133 & 120 & 114 & 113 & 189 & 134 & 200 & & & \\
\hline Human AMACR & $\mathrm{L}$ & $\mathrm{F}$ & $\mathrm{F}$ & $\mathrm{G}$ & $\mathrm{V}$ & $\mathrm{S}$ & W & & 4 & 5 \\
\hline Mouse AMACR & $\mathrm{L}$ & $\mathrm{F}$ & $\mathrm{F}$ & $\mathrm{G}$ & $\mathrm{V}$ & $\mathrm{S}$ & $\mathrm{W}$ & & 4 & 5 \\
\hline Mimotope \# 2 & $\mathrm{~L}$ & $\mathrm{~K}$ & $\mathrm{Y}$ & $\mathrm{G}$ & Q & $\mathrm{H}$ & $\mathrm{R}$ & $1 / 10$ & & \\
\hline MRC & $\mathrm{L}$ & $\mathrm{S}$ & $\mathrm{Y}$ & $\mathrm{G}$ & $\mathrm{Q}$ & $\mathrm{Q}$ & $\mathrm{R}$ & & 5 & 5 \\
\hline PGAA & 133 & 132 & 130 & 125 & 123 & 122 & 120 & & & \\
\hline Human AMACR & $\mathrm{L}$ & $\mathrm{A}$ & $\mathrm{Y}$ & $\mathrm{G}$ & $\mathrm{L}$ & $\mathrm{R}$ & $\mathrm{F}$ & & 3 & 5 \\
\hline Mouse AMACR & $\mathrm{L}$ & A & $\mathrm{Y}$ & $\mathrm{G}$ & $\mathrm{V}$ & $\mathrm{K}$ & $\mathrm{F}$ & & 3 & 5 \\
\hline \multicolumn{11}{|l|}{$13 \mathrm{H} 4$} \\
\hline Mimotope \# 1 & $\mathrm{~W}$ & $\mathrm{~W}$ & $\mathrm{~W}$ & $\mathrm{~S}$ & $\mathrm{~L}$ & Q & $\mathrm{P}$ & $5 / 10$ & & \\
\hline $\mathrm{MRC}$ & & $\mathrm{W}$ & $\mathrm{Y}$ & $\mathrm{S}$ & $\mathrm{L}$ & $\mathrm{R}$ & $\mathrm{P}$ & & 4 & 4 \\
\hline PGAA & & 114 & 130 & 132 & 133 & 120 & 119 & & & \\
\hline Human AMACR & & $\mathrm{F}$ & $\mathrm{Y}$ & $\mathrm{A}$ & $\mathrm{L}$ & $\mathrm{F}$ & $\mathrm{S}$ & & 1 & 4 \\
\hline Mouse AMACR & & $\mathrm{F}$ & $\mathrm{Y}$ & $\mathrm{A}$ & $\mathrm{L}$ & $\mathrm{F}$ & I & & 1 & 4 \\
\hline Mimotope \# 2 & $\mathrm{H}$ & $\mathrm{K}$ & $\mathrm{S}$ & $\mathrm{L}$ & $\mathrm{G}$ & $\mathrm{T}$ & $\mathrm{W}$ & $1 / 10$ & & \\
\hline $\mathrm{MRC}$ & $\mathrm{H}$ & $\mathrm{N}$ & $\mathrm{S}$ & $\mathrm{L}$ & G & $\mathrm{N}$ & $\mathrm{W}$ & & 5 & 6 \\
\hline PGAA & 126 & 129 & 132 & 133 & 135 & 134 & 200 & & & \\
\hline Human AMACR & $\mathrm{H}$ & $\mathrm{N}$ & $\mathrm{A}$ & $\mathrm{L}$ & $\mathrm{G}$ & $\mathrm{S}$ & $\mathrm{W}$ & & 4 & 6 \\
\hline Mouse AMACR & $\mathrm{H}$ & $\mathrm{N}$ & $\mathrm{A}$ & $\mathrm{L}$ & G & $\mathrm{S}$ & $\mathrm{W}$ & & & \\
\hline \multicolumn{11}{|l|}{$2 \mathrm{~A} 5$} \\
\hline Mimotope \# 1 & $\mathrm{~F}$ & $\mathrm{P}$ & $\mathrm{T}$ & $\mathrm{F}$ & $\mathrm{P}$ & $\mathrm{N}$ & $\mathrm{Q}$ & $1 / 10$ & & \\
\hline MRC & $\mathrm{F}$ & $\mathrm{P}$ & $\mathrm{T}$ & I & $\mathrm{P}$ & $\mathrm{N}$ & $\mathrm{E}$ & & 5 & 2 \\
\hline PGAA & 319 & 328 & 318 & 3133 & 311 & 309 & 310 & & & \\
\hline Human AMACR & $\mathrm{N}$ & $\mathrm{P}$ & $\mathrm{S}$ & $\mathrm{N}$ & $\mathrm{D}$ & $\mathrm{H}$ & $\mathrm{H}$ & & 2 & 2 \\
\hline Mouse AMACR & $\mathrm{N}$ & $\mathrm{P}$ & S & $\mathrm{N}$ & $\mathrm{Q}$ & $\mathrm{H}$ & $\mathrm{H}$ & & 2 & 2 \\
\hline Mimotope \# 2 & $\mathrm{~T}$ & $\mathrm{P}$ & S & $\mathrm{N}$ & K & $\mathrm{H}$ & $\mathrm{T}$ & $1 / 10$ & & \\
\hline MRC & & $\mathrm{P}$ & $\mathrm{T}$ & $\mathrm{N}$ & $\mathrm{R}$ & $\mathrm{H}$ & & & 3 & 4 \\
\hline PGAA & & 328 & 318 & 3173 & 316 & 312 & & & & \\
\hline Human AMACR & & $\mathrm{P}$ & $\mathrm{S}$ & $\mathrm{G}$ & $\mathrm{R}$ & $\mathrm{H}$ & & & 3 & 4 \\
\hline Mouse AMACR & & $\mathrm{P}$ & S & A & $\mathrm{R}$ & $\mathrm{H}$ & & & 3 & 4 \\
\hline Mimotope \# 3 & $\mathrm{~N}$ & $\mathrm{~N}$ & I & $\mathrm{L}$ & $\mathrm{P}$ & M & $\mathrm{T}$ & $1 / 10$ & & \\
\hline MRC & $\mathrm{N}$ & $\mathrm{E}$ & I & $\mathrm{F}$ & $\mathrm{P}$ & M & $\mathrm{T}$ & & 5 & 2 \\
\hline PGAA & 309 & 310 & 313 & 3193 & 328 & 329 & 318 & & & \\
\hline Human AMACR & $\mathrm{H}$ & $\mathrm{H}$ & $\mathrm{N}$ & $\mathrm{F}$ & $\mathrm{P}$ & $\mathrm{R}$ & $\mathrm{S}$ & & 1 & 2 \\
\hline Mouse AMACR & $\mathrm{H}$ & $\mathrm{H}$ & $\mathrm{N}$ & $\mathrm{F}$ & $\mathrm{P}$ & $\mathrm{R}$ & S & & 1 & 2 \\
\hline Mimotope \# 4 & $\mathrm{~W}$ & $\mathrm{G}$ & $\mathrm{F}$ & $\mathrm{P}$ & $\mathrm{Y}$ & $\mathrm{K}$ & & $1 / 10$ & & \\
\hline MRC & $\mathrm{W}$ & $\mathrm{G}$ & $\mathrm{Y}$ & $\mathrm{P}$ & $\mathrm{F}$ & $\mathrm{Q}$ & & & 3 & 1 \\
\hline PGAA & 326 & 325 & 319 & 3283 & 318 & 327 & & & & \\
\hline Human AMACR & $\mathrm{V}$ & $\mathrm{D}$ & I & $\mathrm{P}$ & $\mathrm{F}$ & $\mathrm{S}$ & & & 1 & 1 \\
\hline Mouse AMACR & $\mathrm{P}$ & $\mathrm{L}$ & I & $\mathrm{P}$ & $\mathrm{F}$ & $\mathrm{S}$ & & & 1 & 1 \\
\hline
\end{tabular}

Peptide mimotopes sequences were identified during screening of the phage peptide library PhD-7C7 by in-house made and commercial antibodies against AMACR followed by the sequencing of the single chain phage DNA from 10 phage clones selected by each antibody during three rounds of biopanning. The antibody epitope mapping was performed using the program Pepitope and crystal structure of the MRC. The homologous sequences of human and mouse AMACR as well as conservative AA in the epitopes were identified by alignment of MRC, human (NP_055139.4) and mouse AMACR (NP_032563.2). PGAA, position of homologous AA in MRC; AA, amino acid residue; epitopes WYSLRP, PTNRH and WGYPFQ are shorter than the corresponding mimotopes on 1-2 AA, which the Pepitope program did not find in MRC. 
1)

2)

3)

9)

10)

11)

1)

2)

3)

4)

9)

10)

11)

1)

4)

9)

10)

11)

9) EPQFYAAMLAGLGLDAAELPQNDRARWPELRALLTEAFASHDRDHWGAVFANSDACVTP 300

10) EPQFYELLIKGLGLKSDELPNQMSMDDWPEMKKKFADVFAEKTKAEWCQIFDGTDACVTP 296

11)

EPQFYALLLKGLGLESEELPSQMSSADWPEMKKKFADVFAKKTKAEWCQIFDGTDACVTP 295

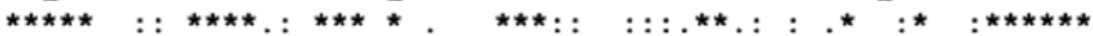

5)

6)

7)

8)

9)

11)

$$
\begin{aligned}
& \text { HQ G } Y \text { KL } \\
& \text { W SL } \\
& \text { H K SLTG }
\end{aligned}
$$

SQQAGHDINYISLNGILHAIGRGDERPVPPLNLVGDFGGGSMFLLVGILAALWERQSSGK 180

CRLAGHDINYLALSGVLSKIGRSGENPYAPLNLLADFAGGGLMCALGI IMALFDRTRTGK 176

SKVAGHDINYLALSGVLSKIGRSGENPYPPLNLLADFGGGGLMCTLGIVLALFERTRSGR 175

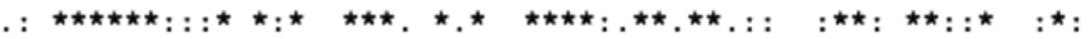

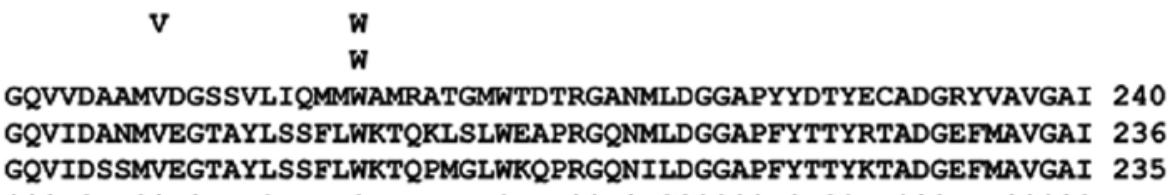

$\mathrm{V}$

W

GQVVDAAMVDGSSVLIQMMWAMRATGMWTDTRGANMLDGGAPYYDTYECADGRYVAVGAI 240

GQVIDANMVEGTAYLSSFLWKTQKLSLWEAPRGQNMLDGGAPFYTTYRTADGEFMAVGAI 236

GQVIDSSMVEGTAYLSSFLWKTQPMGLWKQPRGQNILDGGAPFYTTYKTADGEFMAVGAI 235

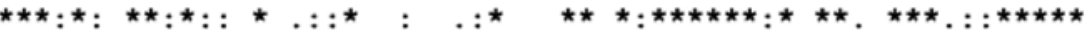

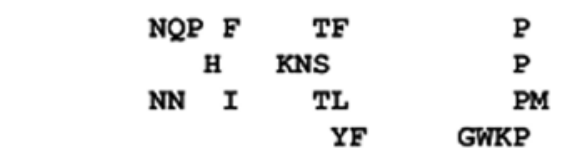

VLAFGEVHNEPHIIERNTFYEANG-GWQPMPAPRFSRTASS--QPRPPAATIDIEAVLTD 357

VLTFEEVVHHDHNKERGSFITSEEQDVSPRPAPLLLNTPAIPSFKRDPFIGEHTEEILEE 356

VLTFEEALHHQHNRERASFITDGEQLPSPRPAPLLSRTPAVPSAKRDPSVGEHTVEVLRE 355

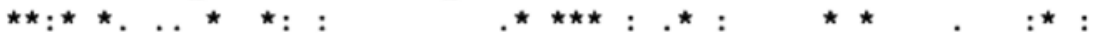

Figure 3. Alignment of various AMACR polypeptides: 1-2) LKWGVHW and LKYGQHR phage mimotopes detected by 6H9 antibody; 3-4) WWWSLQP and HKSLGTW phage mimotopes detected by the $13 \mathrm{H} 4$ antibody; 5-8) FPTFPNQ, TPSNKHT, NNILPMT, PWGFPYK phage mimotopes detected by the $2 \mathrm{~A} 5$ antibody; 9) MRC, PDB 1x74, 10) human AMACR, NP_055139.4; 11) mouse AMACR, NP_032563.2. (*), identical AA; (:), highly conservative AA, more 0.5 point using matrix Gonnet PAM 250, (-), low conservative AA, 0.5 and less point. WYSLRP, SNKHP and WGFPYK epitope sequences are shorter than the corresponding mimotopes on 1-2 AA which the program Pepitope did not identified in MRC.

tional units) to the epitope cluster of MRC comprising N309, E310, P311, H312, I313, R316, N317, W318, F319, Y320, G325, W326, Q327, P328 and M329 (Fig. 3).

All AA forming the epitopes recognized by the $6 \mathrm{H} 9$ and 13H4 antibodies were located in the region of MRC, composed of helices $\alpha 5$ and $\alpha 8$, and unstructured sequence between helices $\alpha 5$ and $\alpha 6$, helix $\alpha 5$ and sheet $\beta 5$ (Fig. 4). The vast number of the AA forming these epitopes, 24 out of 27, were located between helices $\alpha 5$ and $\alpha 6$, helix $\alpha 5$ and sheet $\beta 5$, whereas in the region of helix $\alpha 8$, there were mapped only 3 AA (Table I). The epitopes recognized by the $6 \mathrm{H} 9$ and $13 \mathrm{H} 4$ antibodies indicated high levels of conservatism, 71/69\%, $50 / 38 \%$ and $71 / 77 \%$ of their AA were identical, respectively, in MRC, human or mouse AMACR and conservative. The epitopes detected by the $6 \mathrm{H} 9$ and $13 \mathrm{H} 4$ antibodies in human or mouse AMACR were virtually identical (Table I).

The epitopes recognized by the 2A5 antibody, which was used as a negative control localized in the helix $\alpha 13$ and sheets 10-11 of MRC, that represent a different region of the AMACR fold compared with the region between helices $\alpha 5$ and $\alpha 8$, in which the epitopes of the $6 \mathrm{H} 9$ and $13 \mathrm{H} 4$ antibodies were localized (Fig. 3). Of note, despite the high levels of identity of phage mimotopes and MRC epitopes recognized by the 2A5 antibody (64\% identity), these sequences revealed low levels of conservatism (36\%). When compared with homologous sequences in mouse and human AMACR the levels of their identity and conservatism were, respectively, 28 and $36 \%$ (Table I) (the percentage identity scores were obtained by dividing the number of identical AA by the total number of AA in all mimotopes).

Growth-associated activity of the $6 \mathrm{H} 9$ antibody against $A M A C R$. To examine the growth-associated activity of the $6 \mathrm{H} 9$ antibody, we first tried to deliver the antibody into cells using a liposome-based PULSin reagent (Polyplustransfection). For these experiments, we exploited HeLa human cervical adenocarcinoma cells, which produce high levels of AMACR (Figs. 1C and 2B) and exhibit a high sensitivity in antibody delivery with PULSin reagent (32). AMACR catalyzes the oxidation of fatty acids and is localized in peroxisomes and mitochondria. The $6 \mathrm{H} 9$ antibody similar, to the commercially available 63340 antibody 


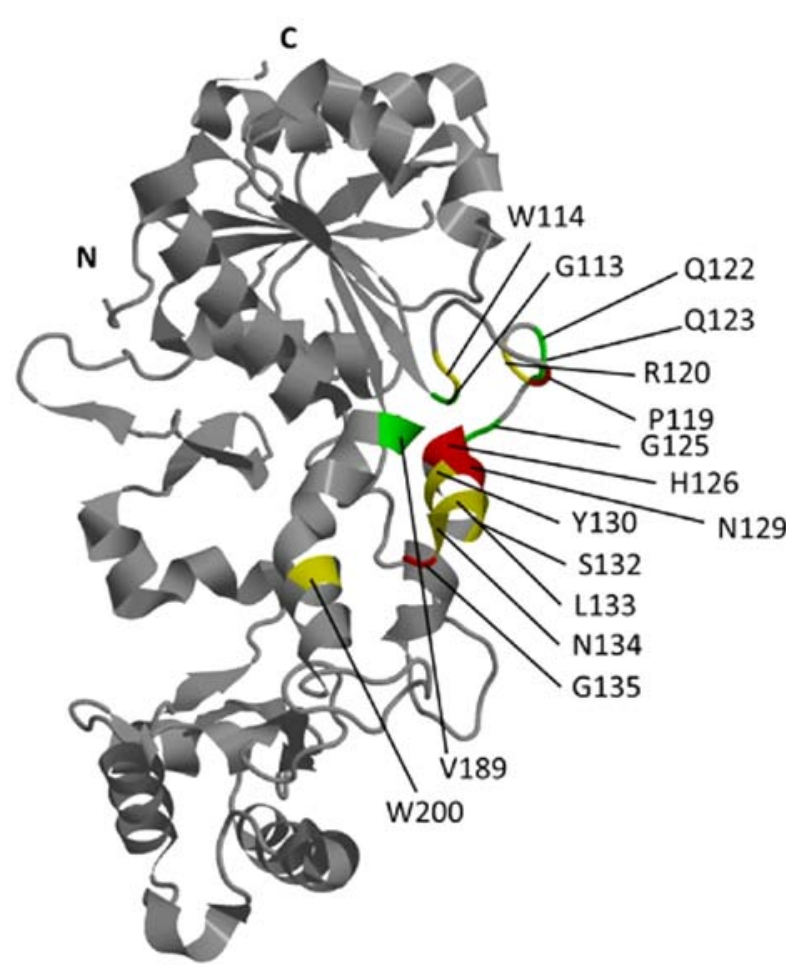

Figure 4. Localization of the conformation epitopes of AMACR recognized by the $6 \mathrm{H} 9$ and $13 \mathrm{H} 4$ antibodies in the monomer fold of MRC. AA recognized by $6 \mathrm{H} 9$ antibody shown in green, by $13 \mathrm{H} 4$ antibody shown in red, by both antibodies shown in yellow. Epitope mapping was performed using the program Pepitope, algorithm PepSurf and the crystal structure of MRC.

(Abcam), detected abundant amounts of AMACR in HeLa cells (Fig. 5A). In HeLa cells treated with paraformaldehyde, AMACR was mostly detected outside peroxisomes, observed in both preparations stained with $6 \mathrm{H} 9$ or 63340 antibodies (Fig. 5B). The distribution pattern of specific $6 \mathrm{H} 9$ and 63340 antibodies proteofected into HeLa cells was similar and differed from that of non-specific 2A5 antibody. While specific antibodies were distributed over the entire cytoplasm compartment preferentially in the form of small particles, non-specific antibody forms large cytoplasmic clusters, often connected in chains near or around the nuclei (Fig. 5C). The levels of co-localization with peroxisomes of different antibodies against AMACR proteofected into HeLa cells depended on the type of antibody used. While non-specific 2A5 antibody did not exhibit any co-localization (Fig. 5D), 6H9 antibody, low level and 63340 antibody, exhibited a greater level of co-localization visible due to the change in the color of peroxisomes from green to yellow (Fig. 5D). The growth rate of the HeLa and T98G cells proteofected with antibody $6 \mathrm{H} 9$ or non-specific antibody $2 \mathrm{~A} 5$ was similar when determined using growth curves or MTT assay (Fig. 6).

\section{Discussion}

AMACR localizes in peroxisomes and mitochondria (33), where it catalyzes the racemization of $(\alpha \mathrm{R})$-methylacyl-CoA esters required for the synthesis of bile acids and ATP during subsequent $\beta$-oxidation (34-36). Mouse AMACR is encoded by a single gene and comprises at the $\mathrm{N}$ - and $\mathrm{C}$-terminus the specific sequences regulating input, respectively, in
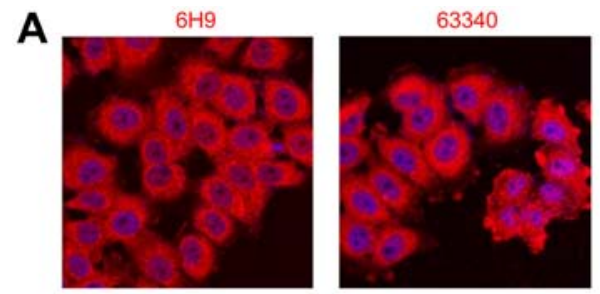

B

Per $+6 \mathrm{H} 9$

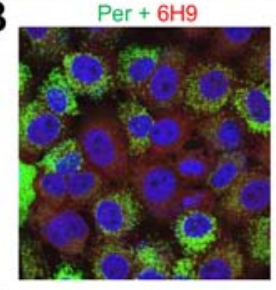

C

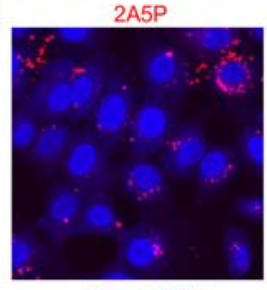

$\mathbf{D}$
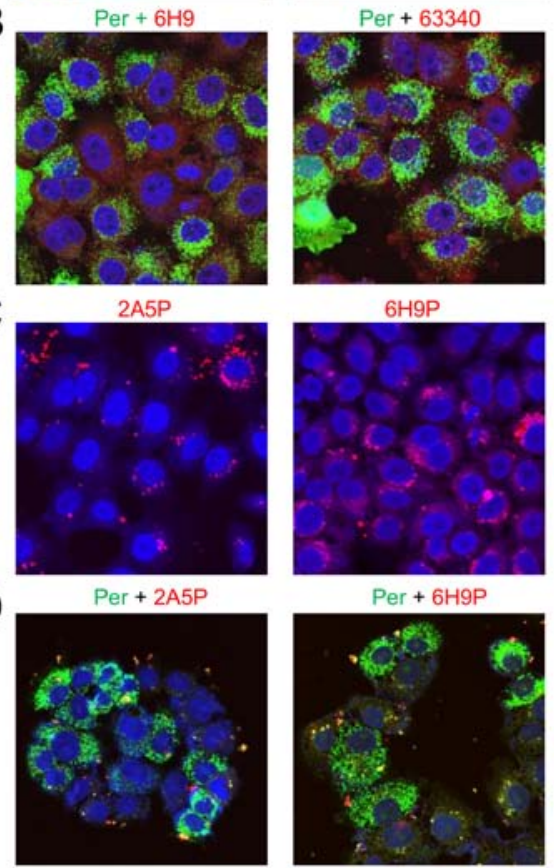

$6 \mathrm{H} 9 \mathrm{P}$

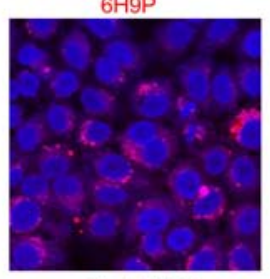

Per $+6 \mathrm{H} 9 \mathrm{P}$
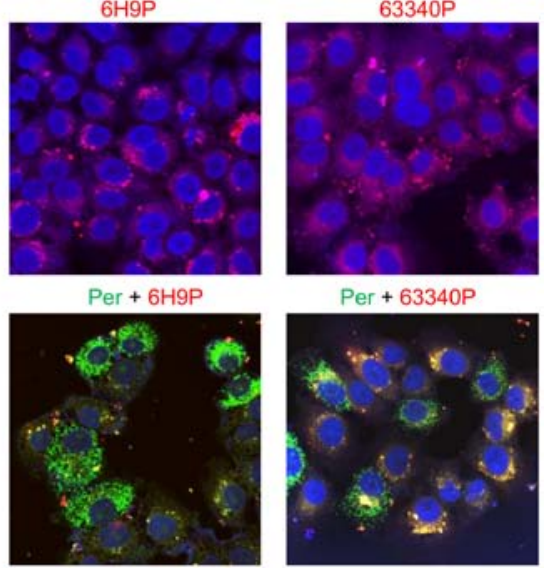

Per $+63340 P$

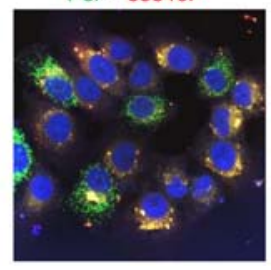

Figure 5. Immunofluorescent evaluation of AMACR co-localization with peroxisomes in HeLa cells proteofected with different antibodies against AMACR. (A) AMACR visualization, accordingly, with in-house made $6 \mathrm{H} 9$ and commercial ab63340 (Abcam) antibodies in fixed cells; (B) AMACR co-localization with peroxisomes in fixed cells stained, accordingly, with $6 \mathrm{H} 9$ or ab63340 antibodies; (C) cytoplasmic distribution of non-specific 2A5, specific $6 \mathrm{H} 9$ or ab63340 antibodies to AMACR proteofected into live cells; (D) co-localization with peroxisomes of non-specific 2A5, specific $6 \mathrm{H} 9$ or ab63340 antibodies proteofected into live cells. The positive staining is shown in red and yellow. The images were recorded on Olympus FV3000 confocal scanning microscope using lasers with 405, 488 and $561 \mathrm{~nm}$ wavelength, with a X40 objective; the size of the images is $159 \mu \mathrm{m}$. P, proteofection; Per, peroxisomes. Each experiment was repeated 3-5 times.

mitochondria and peroxisomes (37). There are 10 different isoforms of AMACR in humans, but only the $1 \mathrm{~A}$ isoform encoding a protein with the reading frame of $382 \mathrm{AA}$ is functionally the most important (38). Enzymatically, AMACR, independently on cofactors, reversibly converts the R and $\mathrm{S}$ asymmetric position of 2 carbon atom of the methyl group of 2-methyl-thioester. AMACR belongs to the family III of CoA transferases (39), members of which catalyze the transfer of a proton of the carbon atom directly performed by two AA $(1,2)$. In order to study the atomic structure of the AMACR catalytic center, it was described as a model the crystal structure of AMACR of MRC, which has 41 and $43 \%$ sequence identity to the mouse and human protein, but in contrast to mammals, MRC is expressed in an active form in a bacterial system (1). In a native form, AMACR exists as $89 \mathrm{kDa}$ dimer, while the monomeric form MW is $39 \mathrm{kDa}$.

The monomeric form of AMACR is composed of two domains: A large $\mathrm{N}$-terminal and small $\mathrm{C}$-terminal. Two linker sequences, $\alpha 8$ and $\alpha 12-\beta 11$, respectively connect these domains 
A
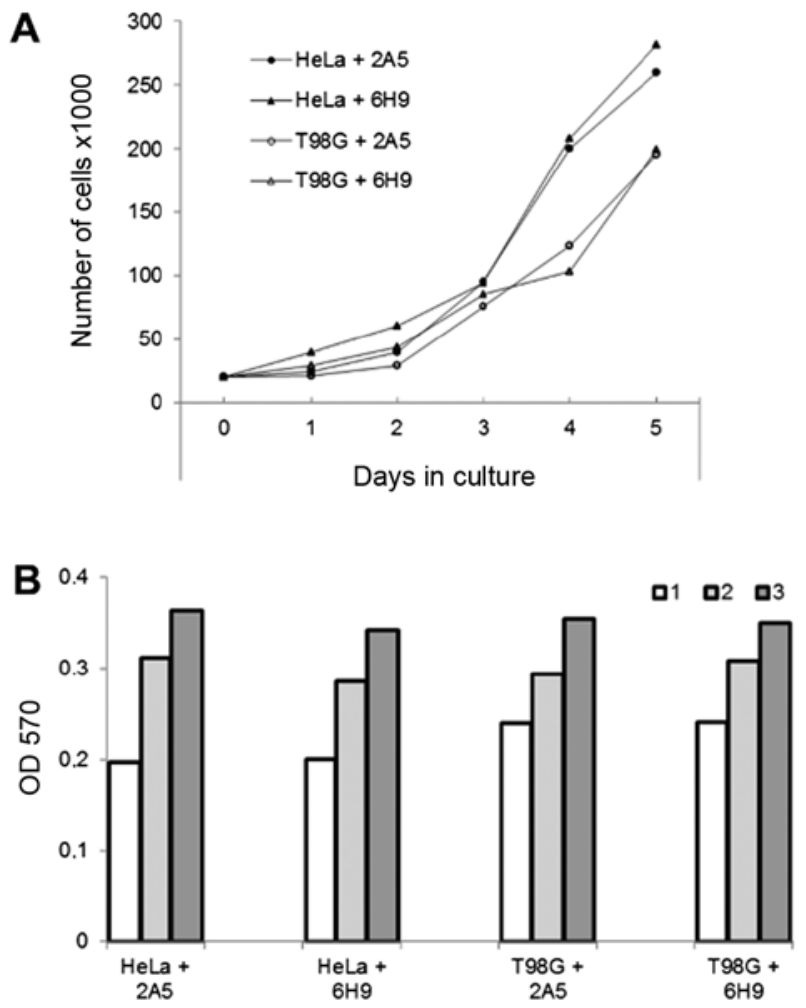

Figure 6. Cell growth associated activity of antibody against AMACR. (A and B) Growth curves and MTT assay of HeLa and T98G cells proteofected with non-specific $2 \mathrm{~A} 5$ or specific $6 \mathrm{H} 9$ antibodies against AMACR The cells were proteofected with each type of the antibody in wells of 24-well plate and transferred the following day into a 96 -well plate to calculate their number in triplicate every day for the following 5 days. A total of $2 \times 10^{4}$ and $5 \times 10^{3}$ cells per one well of a 96 -well plate were transferred, accordingly, for the estimation of growth curves or MTT assay; bars labeled 1,2, 3 indicate days after proteofection. Data are expressed as the mean. Each experiment was repeated at least 3 times.

and the C-terminal helix $\alpha 14$, in which a three-dimensional protein structure associated with the $\mathrm{N}$-domain. The small domain includes residues 224-300 ( $\beta 7-\beta 9)$. The core of the large domain has an open $\alpha / \beta$ structure consisting of 6 layers of the central parallel $\beta$ sheets ( $\beta 1-\beta 6$ ), localized at the sides of the helices. The $\beta 5$ and $\beta 6$ layers are connected by $\alpha 5, \alpha 6$ and $\alpha 7$ helices. The characterization of the catalytic center of MRC by mutagenesis of 26 highly conserved AA showed that a substitution of alanine at 4 of these: Arg91, His126, Asp156 and Glu241, is accompanied by a decrease in enzyme activity, but maintains the correct folding (1). Three of the 4 named AA localized in the N-terminal domain: Arg91, in $\alpha 3$; His126, in $\alpha 5$; Asp156, in $7 \alpha$ helix; whereas Glu241 localized in the C-terminal domain immediately after $\beta 8$. The location of AA showing catalytic activity gave reason to assume that the catalytic center of MRC was located at the interface between the $\mathrm{N}$ - and C-domains, about the N-terminal portion of helix $\alpha 5$ (1). This assumption was confirmed by analyzing the structure of MRC co-crystallized with a variety of substrates (2). It was found that the conversion of isoforms $\mathrm{R}$ and $\mathrm{S}$ of AMACR substrates was carried out by de- and reprotonation of the carbon atom by pair of amino acids: His126/Asp156, which are located, in $\alpha 5$ and $\alpha 7$, respectively through a mechanism called proton transfer $1.1(2,39)$. The active site of the enzyme involves additionally to His126/Asp156 the conservative AA Asp 127, Tyr130,
Asn152, Gly155, Met188 and Glu241 (40). The active enzyme site is located in the MRC dimer interface which is a complex formed by the peptide chains of monomers (41). N-terminal portions of each monomer folded in compact domains that are folded in extensive areas (AA 220-303) reaching the active site of another subunit of the dimer. The 304-360 AA residues form an elongated $\mathrm{C}$-terminal fragment folding in the opposite direction, so that $\mathrm{N}$ - and $\mathrm{C}$-terminal portions are located next to each other. Asp156 played a role of the catalytic base, whereas His126 and Glu241 of other monomer (Glu241) form a pair which acted as the catalytic acid (2).

As a result of biopanning of the phage peptide library with the in-house made monoclonal antibody $6 \mathrm{H} 9$, we selected 10 polypeptides, mimotopes. The homologous epitope in MRC corresponding to the phage mimotopes formed a cluster comprising AA G113, W114, R120, Q122, Q123, A124, G125, Y130, S132, L133, N134, V189 and W200. Commercial rabbit monoclonal antibodies 13H4 against AMACR recognized in the phage library 9 mimotopes, which were most likely to lay in MRC cluster comprising AA W114, P119, R120, H126, I128, N129, Y130, S132, L133, N134, G135 and W200. These abovementioned sequences represent conformational epitopes the vast majority of AA residues of which are localized in the helix $\alpha 5$ and unstructured sequences between helices $\alpha 5, \alpha 6$, and layer $\beta 5$ that is in the catalytic site of the enzyme (Fig. 2). In total, 6 AA residues (W114, R120, Y130, L133, N134 and W200) are common in the epitopes recognized by the $6 \mathrm{H} 9$ and $13 \mathrm{H} 4$ antibodies. These data suggest that the $6 \mathrm{H} 9$ and $13 \mathrm{H} 4$ antibodies recognize similar conformational sequence in the region of AMACR catalytic center (Figs. 3 and 4). From 13 and 12 AA, which form, correspondingly, the $6 \mathrm{H} 9$ and 13H4 antibodies epitopes in MRC, 10 and 9 are identical or conserved, while 10 and 8 of those are identical in human and mice (Fig. 3). These levels of identity correspond to the antibodies specificity in immunoblotting and immunofluorescence, which bound AMACR in various human and mouse tissues and cell lines (Figs. 1 and 2A and B).

AMACR is overexpressed in carcinoma of the prostate, colon, kidney and other tissues $(6,18)$, while the inhibition of its enzyme activity prevents the growth of cancer cells $(8,9)$. AMACR is regarded as a potential target of anticancer therapy. Modern anti-AMACR drugs mostly represent substances with substrate specificity (9). In this study, to the best of our knowledge, we present evidence for the first time to indicate that mouse in-house made and rabbit commercial monoclonal antibody against AMACR recognizes the epitopes which are mapped in the catalytic center of the molecule. Our results suggest that antibody against AMACR may modify its enzymatic activity and may potentially inhibit the proliferation of cancer cells overexpressing AMACR. To evaluate this possibility, we tried to deliver antibody to AMACR in live HeLa cells followed by an estimation of their co-localization with peroxisomes in which AMACR performs its function. AMACR was abundantly produced by HeLa cells and evenly detected in immunofluorescence by the in-house made $6 \mathrm{H} 9$ and commercially available 63340 antibody purchased from Abcam (Fig. 5A). In fixed cells, AMACR did not exhibit co-localization with peroxisomes (Fig. 5B), possibly as the antigen conformation in peroxisomes induced by paraformaldehyde. This suggestion is supported by results of following 
experiments, in which the same antibodies proteofected into live cells were at least partly co-localized with peroxisomes (Fig. 5C and D). For antibody delivery into live cells, we used cationic lipid-based PULSin reagent which forms a noncovalent complex with antibody and releases the antibody in cytoplasm in its native functional form (32). The delivery of non-specific $2 \mathrm{~A} 5$ antibody to HeLa cells resulted in the formation of big cytoplasmic clusters which, presumably, represent endosomes with accumulated antibody (Fig. 5C). Specific antibody to AMACR delivered into live cells distributed evenly (Fig. 5C) and at least partly co-localized with peroxisomes (Fig. 5D). The in-house made 6H9 antibody exhibited a low level of co-localization compared to commercially available 63340 antibody (Fig. 5D). This may be associated with the low capability of $6 \mathrm{H} 9$ antibody to precipitate AMACR from solution (Fig. 1D) due to a low affinity to the native antigen conformation. In accordance with this suggestion, 6H9 antibody when delivered into HeLa or T98G cells, did not inhibit their proliferation rate estimated by the detection of growth curves or MTT assay (Fig. 6). On the whole, our data suggest that antibodies (namely ab63340) against AMACR represent potential therapeutic drugs with which to inactivate the protein and inhibit cancer cell proliferation. Further studies are warranted in order to explore possibilities for preparation of antibody recognizing AMACR with high affinity in native conformation and for efficient antibody delivery to its target.

\section{Acknowledgements}

Immunofluorescence data acquisition and analysis were performed through the Institute of Cytology Cell Imaging Shared Resource. We thank Dr I. Popova, Manager of the Recombinant Protein Production Core at the Northwestern University, Chicago, IL, USA for excellent technical assistance. The Saos 2 human osteosarcoma cells were kindly provided by Dr K. Helin (European Institute of Oncology, Milan, Italy). This study was supported by the Russian Research Foundation grant no. 14-50-00068 and the Russian Foundation for Basic Research grant no. 16-04-00251 (to B.V. Popov).

\section{References}

1. Savolainen K, Bhaumik P, Schmitz W, Kotti TJ, Conzelmann E, Wierenga RK and Hiltunen JK: Alpha-methylacyl-CoA racemase from Mycobacterium tuberculosis. Mutational and structural characterization of the active site and the fold. J Biol Chem 280 12611-12620, 2005.

2. Bhaumik P, Schmitz W, Hassinen A, Hiltunen JK, Conzelmann E and Wierenga RK: The catalysis of the 1,1-proton transfer by alpha-methyl-acyl-CoA racemase is coupled to a movement of the fatty acyl moiety over a hydrophobic, methionine-rich surface. J Mol Biol 367: 1145-1161, 2007.

3. Lloyd MD, Darley DJ, Wierzbicki AS and Threadgill MD: Alpha-methylacyl-CoA racemase--an 'obscure' metabolic enzyme takes centre stage. FEBS J 275: 1089-1102, 2008.

4. Lloyd MD, Yevglevskis M, Lee GL, Wood PJ, Threadgill MD and Woodman TJ: $\alpha$-Methylacyl-CoA racemase (AMACR) Metabolic enzyme, drug metabolizer and cancer marker P504S. Prog Lipid Res 52: 220-230, 2013.

5. Baron A, Migita T, Tang D and Loda M: Fatty acid synthase: A metabolic oncogene in prostate cancer? J Cell Biochem 91: 47-53, 2004.

6. Jiang Z, Fanger GR, Woda BA, Banner BF, Algate P, Dresser K, $\mathrm{Xu}$ J and Chu PG: Expression of alpha-methylacyl-CoA racemase (P504s) in various malignant neoplasms and normal tissues: Astudy of 761 cases. Hum Pathol 34: 792-796, 2003.
7. Rohrmann S, Platz EA, Kavanaugh CJ, Thuita L, Hoffman SC and Helzlsouer KJ: Meat and dairy consumption and subsequent risk of prostate cancer in a US cohort study. Cancer Causes Control 18: 41-50, 2007.

8. Carnell AJ, Hale I, Denis S, Wanders RJ, Isaacs WB, Wilson BA and Ferdinandusse S: Design, synthesis, and in vitro testing of alpha-methylacyl-CoA racemase inhibitors. J Med Chem 50: 2700-2707, 2007.

9. Carnell AJ, Kirk R, Smith M, McKenna S, Lian LY and Gibson R: Inhibition of human $\alpha$-methylacyl CoA racemase (AMACR): A target for prostate cancer. ChemMedChem 8: 1643-1647, 2013.

10. Schmitz W, Fingerhut R and Conzelmann E: Purification and properties of an alpha-methylacyl-CoA racemase from rat liver. Eur J Biochem 222: 313-323, 1994

11. Xu J, Stolk JA, Zhang X, Silva SJ, Houghton RL, Matsumura M, Vedvick TS, Leslie KB, Badaro R and Reed SG: Identification of differentially expressed genes in human prostate cancer using subtraction and microarray. Cancer Res 60: 1677-1682, 2000.

12. Jiang Z, Woda BA, Rock KL, Xu Y, Savas L, Khan A, Pihan G, Cai F, Babcook JS, Rathanaswami P, et al: P504S: A new molecular marker for the detection of prostate carcinoma. Am J Surg Pathol 25: 1397-1404, 2001.

13. Luo J, Zha S, Gage WR, Dunn TA, Hicks JL, Bennett CJ, Ewing CM, Platz EA, Ferdinandusse S, Wanders RJ, et al: Alpha-methylacyl-CoA racemase: A new molecular marker for prostate cancer. Cancer Res 62: 2220-2226, 2002.

14. Zhou M, Chinnaiyan AM, Kleer CG, Lucas PC and Rubin MA: Alpha-Methylacyl-CoA racemase: A novel tumor marker overexpressed in several human cancers and their precursor lesions. Am J Surg Pathol 26: 926-931, 2002.

15. Rubin MA, Zhou M, Dhanasekaran SM, Varambally S, Barrette TR, Sanda MG,Pienta KJ, Ghosh D and Chinnaiyan AM: alpha-Methylacyl coenzyme A racemase as a tissue biomarker for prostate cancer. JAMA 287: 1662-1670, 2002.

16. Jiang Z, Woda BA, Wu CL and Yang XJ: Discovery and clinical application of a novel prostate cancer marker: Alpha-methylacyl CoA racemase (P504S). Am J Clin Pathol 122: 275-289, 2004.

17. Adley BP and Yang XJ: Application of alpha-methylacyl coenzyme A racemase immunohistochemistry in the diagnosis of prostate cancer: A review. Anal Quant Cytol Histol 28: 1-13, 2006.

18. Kapoor S: AMACR: An emerging diagnostic and prognostic tool in systemic malignancies. Int Urol Nephrol 45: 439-440, 2013.

19. Chen W, Wu W, Zhao J, Yu C, Liu W, Jiang A and Zhang J: Molecular cloning and preliminary analysis of the human alphamethylacyl-CoA racemase promoter. Mol Biol Rep 36: 423-430, 2009.

20. Sekine S, Ogawa R, Ojima $\mathrm{H}$ and Kanai Y: Overexpression of $\alpha$-methylacyl-CoA racemase is associated with CTNNB1 mutations in hepatocellular carcinomas. Histopathology 58: 712-719, 2011.

21. Nusse R and Clevers H: Wnt/ $\beta$-catenin signaling, disease, and emerging therapeutic modalities. Cell 169: 985-999, 2017.

22. Bosetti C, Bertuccio P, Malvezzi M, Levi F, Chatenoud L, Negri E and La Vecchia C: Cancer mortality in Europe, 2005-2009, and an overview of trends since 1980. Ann Oncol 24: 2657-2671, 2013.

23. Honma I, Torigoe T, Hirohashi Y, Kitamura H, Sato E, Masumori N, Tamura Y, Tsukamoto T, Sato N and Sato N: Aberrant expression and potency as a cancer immunotherapy target of alpha-methylacyl-coenzyme A racemase in prostate cancer. J Transl Med 7: 103, 2009.

24. Lin PY, Cheng KL, McGuffin-Cawley JD, Shieu FS, Samia AC, Gupta S, Cooney M, Thompson CL and Liu CC: Detection of alpha-methylacyl-CoA racemase (AMACR), a biomarker of prostate cancer, in patient blood samples using a nanoparticle electrochemical biosensor. Biosensors (Basel) 2: 377-387, 2012.

25. Nickens KP, Ali A, Scoggin T, Tan SH, Ravindranath L, McLeod DG, Dobi A, Tacha D, Sesterhenn IA, Srivastava S, et al: Prostate cancer marker panel with single cell sensitivity in urine. Prostate 75: 969-975, 2015.

26. Mayrose I, Penn O, Erez E, Rubinstein ND, Shlomi T, Freund NT, Bublil EM, Ruppin E, Sharan R, Gershoni JM, et al: Pepitope: Epitope mapping from affinity-selected peptides. Bioinformatics 23: 3244-3246, 2007.

27. Mayrose I, Shlomi T, Rubinstein ND, Gershoni JM, Ruppin E, Sharan R and Pupko T: Epitope mapping using combinatorial phage-display libraries: A graph-based algorithm. Nucleic Acids Res 35: 69-78, 2007. 
28. Liu HM, Newbrough SE, Bhatia SK, Dahle CE, Krieg AM and Weiner GJ: Immunostimulatory $\mathrm{CpG}$ oligodeoxynucleotides enhance the immune response to vaccine strategies involving granulocyte-macrophage colony-stimulating factor. Blood 92 3730-3736, 1998.

29. Popov B and Kaczmarek L: Antibody raised to the short sequence from the zinc-finger domain of the EGR-1 recognizes $102 \mathrm{KD}$ protein in mouse fibroblasts. Biochem Mol Biol Int 32: 39-47, 1994.

30. Negi SS and Braun W: Automated detection of conformational epitopes using phage display Peptide sequences. Bioinform Biol Insights 3: 71-81, 2009.

31. Petrov NS and Popov BV: Study of Wnt 2 secreted by A-549 cells in paracrine activation of $\beta$-catenin in co-cultured mesenchymal stem cells. Biochemistry (Mosc) 79: 524-530, 2014.

32. Weill CO, Biri S and Erbacher P: Cationic lipid-mediated intracellular delivery of antibodies into live cells. Biotechniques 44: Pvii-Pxi, 2008

33. Amery L, Fransen M, De Nys K, Mannaerts GP and Van Veldhoven PP: Mitochondrial and peroxisomal targeting of 2-methylacyl-CoA racemase in humans. J Lipid Res 41: 1752-1759, 2000.

34. Pedersen JI, Veggan T and Björkhem I: Substrate stereospecificity in oxidation of (25S)-3 alpha, 7 alpha, 12 alpha-trihydroxy-5 beta-cholestanoyl-CoA by peroxisomal trihydroxy- 5 betacholestanoyl-CoA oxidase. Biochem Biophys Res Commun 224: 37-42, 1996.

35. Hiltunen JK and Qin Y: beta-oxidation - strategies for the metabolism of a wide variety of acyl-CoA esters. Biochim Biophys Acta 1484: 117-128, 2000.
36. Russell DW: The enzymes, regulation, and genetics of bile acid synthesis. Annu Rev Biochem 72: 137-174, 2003.

37. Kotti TJ, Savolainen K, Helander HM, Yagi A, Novikov DK, Kalkkinen N, Conzelmann E, Hiltunen JK and Schmitz W: In mouse alpha -methylacyl-CoA racemase, the same gene product is simultaneously located in mitochondria and peroxisomes. J Biol Chem 275: 20887-20895, 2000.

38. Ouyang B, Leung YK, Wang V, Chung E, Levin L, Bracken B, Cheng L and Ho SM: $\alpha$-Methylacyl-CoA racemase spliced variants and their expression in normal and malignant prostate tissues. Urology 77: 249.e1-249.e7, 2011.

39. White WB, Coleman JP and Hylemon PB: Molecular cloning of a gene encoding a 45,000-dalton polypeptide associated with bile acid 7-dehydroxylation in Eubacterium sp. strain VPI 12708. J Bacteriol 170: 611-616, 1988.

40. Sharma S, Bhaumik P, Schmitz W, Venkatesan R, Hiltunen JK, Conzelmann E, Juffer AH and Wierenga RK: The enolization chemistry of a thioester-dependent racemase: The $1.4 \AA$ crystal structure of a reaction intermediate complex characterized by detailed QM/MM calculations. J Phys Chem B 116: 3619-3629, 2012.

41. Li X, Zheng QC and Zhang HX: Quantum chemical modeling of 1,1-proton transfer reaction catalyzed by a cofactor-independent a-methylacyl-CoA racemase. Int J Quantum Chem 112: 619-624, 2012. 